\begin{tabular}{c} 
Volume and Issues Obtainable at Center for Sustainability Research and Consultancy \\
Review of Politics and Public Policy in Emerging Economies \\
ISSN: $2708-3829$ \& (E): 2708-356X \\
Volume 3: No. 1, June 2021 \\
CSRC \\
Journal homepage: $\underline{\text { www.publishing.globalcsrc.org/rope }}$ \\
\hline
\end{tabular}

\title{
Re-Thinking Models of Judicial Appointments in the Superior Courts of Pakistan: A Quest for a Better Model
}

*Rao Imran Habib, Assistant Professor, University Gillani Law College, Bahauddin Zakariya University Multan, Pakistan

*Corresponding author's email: raoimran@bzu.edu.pk

\begin{tabular}{l}
\hline ARTICLE DETAILS \\
\hline History \\
Revised format: May 2021 \\
Available Online: Jun 2021
\end{tabular}

\section{Keywords}

Superior Courts, Judicial

Appointments, Judicial

Independence, Constitution,

Executive.

\section{JEL Classification}

K4, K000, K490, K1, K19

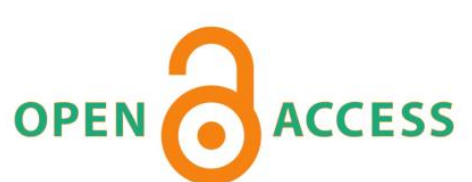

\section{ABSTRACT}

Purpose: Since the inception of the notions of separation of powers and judicial independence, different judicial systems across the globe have devised various models of judicial appointments to meet the standards of the concepts of separation of powers and judicial independence.

Methodology: In general, three moles of judicial appointments namely the politicised, the judicialised and the institutionalised models have been used in different jurisdictions.

Findings: In Pakistan, since its independence, all these three models have been practiced, however none of these could help to achieve the required standards of judicial independence. The causes of failure perhaps rooted in the attitudes and intentions of the constitutional players rather than internal flaws of these three models.

Implications: This article analyses the pros and cons of these models of judicial appointments and the causes of failure of these models in provision of independent and trustworthy judiciary in Pakistan and then proposes a better model with further improvements for judicial appointments in Pakistan.

(C) 2021 The authors, under a Creative Commons AttributionNonCommercial 4.0

\footnotetext{
Recommended citation: Habib, R. I. (2021). Re-Thinking Models of Judicial Appointments in the Superior Courts of Pakistan: A Quest for a Better Model. Review of Politics and Public Policy in Emerging Economies, 3 (1), 51-67.
}

\section{Introduction}

The judicial appointments system has a central position in judicial independence. The fact that the judicial selection procedures for apex courts are generally embedded in the constitutional laws of countries also acknowledges and legitimises the high status of judicial appointments in those countries' constitutional arrangements (Garoupa and Ginsburg 2009, 103; Clarke 2009, 49; Hayo and Voigt 2010, 4-5; Phillips 2011; Roth 2012, 1; Mehsood, Khan and Shah 2017, 26). Once judges are appointed it is very difficult to remove them, irrespective of whether their appointment was on merit only or due to political considerations (Legg 2004, 48-49). The Supreme Court of Pakistan has highlighted the importance of judicial appointments in the following words: "The independence of the Judiciary is inextricably linked and connected with the constitutional process of appointment of Judges of the superior Judiciary" (Al-Jehad Trust v 
Federation of Pakistan 1996, 324).

\section{Models of Judicial Appointments}

In some jurisdictions, particularly in common law jurisdictions, judges are selected from the lines of senior lawyers in the bars. They are often appointed by the executive, which means political domination in the appointment process. In some jurisdictions, the candidates undergo an election process after their initial appointment. In some other jurisdictions, like those with a civil law basis, candidates with certain qualifications appear in competitive exams to become judges and then progress to the higher ranks (UNODC 2006, 11). The diversity of these selection methods suggests a lack of agreement on the best mechanism for judicial appointments which can secure judicial independence (Goldschmidt, Olson and Ekman 2008, 455-56). Shetreet (1987, 766-67) suggests that judicial appointment procedures can be classified in two ways. First, the system can be identified and categorised on the basis of the nature of its process, or, more specifically, whether the system is based on appointments through elections or appointments through selections, or a mixture of both. The second classification can be made on the basis of who makes the selections: the Executive, the Legislature or the Judiciary, or a mixed participation of these institutions in the selection process. Every system has an appointing authority, either the president or the prime minister or the monarch himself. Officially, the final decision in each system lies in the hands of the appointing authority, as is the case in the USA. However, in some systems, especially those in which the appointing authority is bound to act on the advice of the selecting authority, the appointing authority plays only a ceremonial role and the actual decisionmaking power remains in the hands of the selecting authority, as is the case in the UK, Pakistan. In some jurisdictions there also exists a recommending authority, which presents a list of the selected potential candidates for each seat, and the selection authority chooses a suitable candidate from the list (Gill 2012, 8-9). Generally, we can classify judicial appointments systems into three fundamental categories: Politicised Model, Professionalised Model and Judicialised Model.

\section{Politicised Model of Judicial Appointments}

The politicised model is based on a political mechanism with minimal involvement from judicial and legal circles. This model allows judicial appointments to be made by the head of the executive or a minister with the portfolio of law and justice without any involvement of the judicial branch or legal fraternity, as was the case in England prior to the CRA 2005, or may be subject to approval by the legislature, as in the USA. The executive may carry out consultations with certain quarters, such as using a selection panel convened by the executive, and these consultations may either be formal or informal (Roth 2012, 5-6). The executive authority may also gather secret information about the candidate from legal and judicial circles, but that information has no binding effect on the executive. If a culture of honesty and integrity prevails in the society then this system enjoys the benefit of trustworthy information about the qualities and capabilities possessed by the candidates (Jowell 2010, 2-3). However, in this system the consultations are made by a somewhat closed group of elite politicians and senior persons from the legal profession. Therefore, the model carries the risk of self-selection or "cloning" in the process of assessment and the selection of appointees, with the result that a candidate may have the qualities required or prescribed for selection but might fail to inspire the incumbents because he might not possess those qualities which are usually associated with them (Davis and Williams $2003,819,835)$. Another primary disadvantage associated with this model is that no matter how detached the appointees are in practice, they cannot get rid of the perception of bias because they will have been appointed by the executive's representative without using an open and lucent procedure (Jowell 2010, 3). It is already perceived that governments in power consider this authority to be an instrument of influence for their policies and political strategies (Office of the High Commissioner for Human Rights 2003, 116; Roth 2012, 15). This system can work only in 
societies where the social and democratic norms and respect for judicial independence are so entrenched that it would be highly improbable for the executive to decide otherwise than on merit. In societies with fragile democracies like Pakistan, this system might be exploited by the executive in its favour.

However, Evans and Williams (2008) believe that the executive should hold absolute power to make judicial appointments because of its political accountability against its decisions. Justice Ronald disagrees, and has argued that: "Political accountability may be present in theory, but in practice is largely illusory, since the effects of a sub-optimal appointment are usually not clear until the Attorney-General responsible has moved on or the Government has lost office" (Quoted in Sackville 2008, 20). If the politically affiliated persons are appointed as judges, then how can we expect fair judicial decisions, and how can this fault be redressed through appealing to political accountability? Wallace $(2001,242)$ answered by arguing that if judges are appointed by politicians, then by ensuring their independence after appointment we can expect them to deliver judgments which are free of any kind of considerations other than the law. This proposition may be true in theory, but in practice the situation is different. Judges are human beings and they possess their own personal and political views. When they are appointed on account of their political ideology, then the risk that they follow the ideology of their appointers in their judgments cannot be completely ruled out. Eventually, control of judicial appointments in the hands of the executive affronts the concepts of separation of powers and judicial independence (Cameron 1990, 67; DCA 2003; Stevens, 2004; Jowell 2010, 3).

In another form of politicised model, judicial appointments are made by the executive subject to approval by parliamentary majority. This system is applied in the USA where the US President appoints a Federal Judge subject to confirmation by a simple majority vote in the US Senate. The Senate scrutinises the appointments through public hearings and approves or disapproves these. Likewise, in Germany the political parties nominate a candidate for judicial appointment and the German House of Parliament approves the nomination by a two-thirds majority. This model legitimises the process of judicial appointments by involving legislative approval. However, in the US only a simple majority is involved in affirmation; hence there may be element of approving candidates deemed favourable to a particular ideology. These candidates might feel themselves bound to pass judgments which satisfy the political ideology of their approvers (Winterton 1987, 198; Jowell 2010, 4). Madison (n.d) defended this model in the US by arguing that the life tenure shields judges against any sense of dependence on, or pressure from, the political parties in the senate; however, this argument has been rebutted as was explained above. Jowell $(2010,4)$ considers the model in Germany more reliable and free from any perception of bias because it involves a two-thirds majority in the Parliament. However, this system may also be subject to doubts when a party gets a two-thirds majority in the parliamentary elections, giving it free rein to choose what it deems to be suitable judges.

Pakistan has a chequered history of judicial appointments. Different rulers have adopted different tactics to control judicial appointments according to their own choices. Since its independence Pakistan adopted various models of judicial appointments. (Waseem 2012, 24; Ibrahim 2010, 2). The Constitution of Pakistan, of 1956, adopted a politicised model for the appointments of High Courts and Supreme Court Judges. The president had the authority to appoint the Chief Justice of Pakistan, while all other Supreme Court Judges were to be appointed by the president after consulting with the Chief Justice of Pakistan. The Chief Justices of the High Courts were to be appointed by the president after consulting with the Governor of the relevant province and the Chief Justice of Pakistan, and in case of appointments of other High Court Judges, the Chief Justice of the concerned High Court would also be consulted. The same model was adopted in Pakistan's subsequent Constitutions, of 1962 and 1973. 
Quite surprisingly, a different procedure was adopted for the appointment of the Federal Shariat Court Judges. According to Article 203-C (2) of the Constitution of Pakistan 1973, the Chief Justice and other judges of the court were to be appointed solely by the president whilst he was not bound to consult anyone. It is noteworthy that the question of whether or not the president was bound to act on the advice given by the Chief Justice of Pakistan during the consultation process was not made clear in any of Pakistan's three Constitutions (Haq 2011, 16). As a matter of practice, the president formerly simply conveyed the names of the proposed judges to the Chief Justice, and this process was called a consultation. If the Chief Justice had a dissenting opinion on a proposed candidate, the president used to ignore that dissent (Iqbal 2012, 18). Hence, the president had sole authority over judicial appointments irrespective of the condition of consultation with the Chief Justice (ICG 2004, 7). The fact that the president was not required to justify why he had not followed the advice of the Chief Justices, created a negative image of the neutrality and impartiality of the appointments system. The appointments in the superior courts were contaminated by political and personal motives. The want of impartiality and transparency in Pakistan's judicial appointments provided a full opportunity to the executive to bring the judiciary under its influence (Siddique 2011, 2; Blue, Hoffman and Berg 2008, 12). Khan (n.d, 2) argued that in fact, the appointment system itself was not defective; rather, the personal interests and ulterior motives of the persons who had the authority to make appointments led the system towards failure. The clarification offered by Khan is not appealing. The system can be argued to have had an inherent flaw in its lack of transparency. The concentration of appointment powers in only one person without instant checks and balances has full potential for misuse, especially in Pakistan's fragile democracy.

This concentration of power in the hands of the executive brought forth negative ramifications. In 1962 Ayub Khan appointed Manzor Qadir, who was at that time serving as a minister in his cabinet, as Chief Justice of the West Pakistan High Court (Shah and Shah 2008, 183; Mian 2004, $36,163)$. He appointed another judge who was a parliamentarian and had casted his vote in favour of Khan on a sensitive issue (Khan 1997, 179). He used to personally interview candidates for the seats of superior court judges, and it was his common practice to accept or reject candidates based on his own personal liking or disliking of them (Khan 1999, 114). Similarly, during his premiership, Zulfiqar Ali Bhutto appointed lawyers as judges who were, prior to their appointments, active members and office bearers of his political party. The motive behind these appointments was that they would be loyal to him and protect his interests and objectives (Shah and Shah 2008, 185; Mehsood, Khan and Shah 2017, 26). Similarly, General Zia and General Musharraf selected only judges who agreed to sanction their Provisional Constitutional Orders (PCOs) and Legal Framework Orders (LFOs). These appointments were clearly in violation of the merit principles which require only persons of integrity and impartiality to be appointed as judges.

\section{Judicialised Model of Judicial Appointments in Pakistan}

The "judicialised model" is based on the process of consultation with judges or legal experts. In this model, despite the fact that the executive has formal power over appointments, the real power rests in the hands of the consultees (Khan and Shah 2003, 22). Gibbs (1987, 43-44) argues that the main feature of consultation in this system might be defeated by the executive. The executive may ignore the advice given in the consultation process. However, in various jurisdictions the executive makes judicial appointments which are subject to a meaningful consultation with the head of the judiciary or the chief of the concerned court (Lee 2010, 371). This model prevents a dishonest government from the appointment of judges according to its will (Mehmood 2020). The view that judges should play their role in the process of appointments to ensure judicial independence is generally accepted at international level. Nevertheless, some also hold an opposite view that considers judicial involvement in the appointment process to be inappropriate. 
For instance, Mahon (As quoted in Winterton 1987, 200-201) has argued that judges may evaluate the practicing skills of advocates; however, they cannot judge their judging abilities. Even if someone agrees with Mahon's argument, this does not mean that the political branches of a state can better judge the judging abilities of the potential candidates. Irrespective of the advantages of the judicialised model, there is a drawback in it which is similar to that of politicised model. The consultation process may give way to the collegial control of the Chief Justice, especially when the Chief Justice is not politically accountable. That is why even in this system, the framers of a constitution have to believe that those who are consulted will act in the national interest rather than according to their own personal political interests (Lee 2010; Gee 2017). The politicised and the judicialised models stand on opposite poles with one commonality, which is that both tend to grant hegemony to one institution or person in the judicial appointments process.

Articles 177 and 193 of the 1973 Constitution of Pakistan provided that the Chief Justices and other Judges of the Supreme Court and High Courts shall be appointed by the president after consultation with the Chief Justice of Pakistan. According to Article 48 (1), the president shall act in accordance with the advice of the cabinet or the prime minister. Further, the Article states that the president was empowered by the 1973 Constitution to require the cabinet or the prime minister to reconsider their advice, but if the advice was reconsidered he was then bound to follow it. However, sub-clause (2) of the same article also declared that notwithstanding clause (1), where the president was empowered to act in his discretion, he could do so and this act could not be questioned on any grounds. Articles 177 and 193 do not specify whether the president shall act on the advice of the prime minister as articulated in Article 48(1) or will act in his discretion under article 48(2). In 1996, Miss Bhutto claimed that the president was bound to act upon her advice, whilst the president insisted that the appointment of judges was at his discretion, and he was not bound to act on the advice of the prime minister (Mullally 2009, 41-42). Prime Minister Sharif presented a unique solution to the problem that the president considered recommendations by every senior official - the Chief Justices of the Supreme Court and High Courts, and the prime minister himself and accommodated all. Every constitutional player therefore got his near and dear ones appointed as judges (Khan 1997, 181). This was an other blatant violation of the merit principle originated by the prime minister.

During her second tenure, Benazir had another dispute with President Laghari over the appointments of judges of the superior courts. The president sent a reference to the Supreme Court for its opinion about the presidential power, while making judicial appointments, to act at his discretion or acting on the advice of the prime minister (Bray 1997, 323). The Supreme Court declared that there was no conflict between Articles 48, 177 and 193 of the Constitution, and added that the president was bound to follow the advice of the prime minister in making judicial appointments in the High Courts and the Supreme Court (Al-Jehad Trust v Federation of Pakistan 1997, 84). However, in both situations the power of appointment remained in the hands of the executive.

Miss Bhutto attempted to appoint judges of her own choice based on favouritism and nepotism. She manoeuvred to gain control of the judiciary by advising the president to appoint as many as 24 ad hoc judges of the Lahore High Court who had strong affiliations with her party (Khan 1997, 181; Bray 1997, 323). The legality of these appointments was challenged before the Supreme Court of Pakistan in the first Al-Jehad Trust v Federation of Pakistan case; this case was also known as the "Judges case". The Supreme Court in its landmark judgment declared these appointments invalid and formulated certain rules for future appointments. This judgment was not challenged in a review petition before the Supreme Court, hence it attained finality and governed future judicial appointments in superior courts until the $18^{\text {th }}$ Constitutional amendment in 2010. The crux of the judgment was that the discretionary power held by the president for 
judicial appointments was restricted and he was bound to follow the advice of the Chief Justice of Pakistan. The Supreme Court declared that the Articles of the Constitution providing for consultation should be read and interpreted in such a manner that makes these consultations "effective, meaningful, purposive, consensus oriented, leaving no room for complaint of arbitrariness or unfair play and involving participatory consultative process between the consultees". The court further declared that the opinion of the Chief Justice of the Supreme Court and the Chief Justice of the relevant High Court regarding fitness and suitability of the proposed candidate should not be rejected unless very sound grounds of rejection were recorded in writing by the president/executive. Mian (Para a) noted that if a candidate is found to be unfit for such an appointment, then the president cannot appoint him as a judge according to the spirit of the Constitution.

The court further held that the acting Chief Justice cannot be a consultee; hence, consultations with the acting Chief Justice cannot fulfil the constitutional requirement of consultation except where the permanent Chief Justice has failed to resume his functions due to continuous illness within 90 days from the date of his sick leave. The Court held that the most senior judge of a High Court has a legitimate expectancy of being considered for appointment as a Chief Justice of that High Court and this rule may only be ignored in the presence of concrete reasons recorded in writing by the president (Para d). This judgment reflected the judgment of the Indian Supreme Court which was passed in 1993 (Supreme Court Advocates - on - Record Association v Union of India 1993). Almost the same issues, along with the interpretation of a consultation clause in the Constitution in binding terms, were discussed by the Indian Supreme Court with the same observations. The Chief Justice Sajjad Ali Shah, being motivated by the Indian Judgment, thought it incumbent to restore judicial independence by sterilizing judicial appointments from political contamination. In his judgment, Shah admitted that "[w]e have to make reference to India time and again for the reason that before the partition it was one country, hence the problems which we are facing today in the present era, are more or less common" (Al-Jehad Trust v Federation of Pakistan 1996, Para 70).

The situation of the superior judiciary in Pakistan at the time of the admission of the petition of the Al-Jehad Trust was not satisfactory. The Supreme Court and the High Courts were filled with ad-hoc or acting judges. Both the Chief Justices of the Lahore High Court and the Sindh High Court were transferred to the Federal Shariat Court for next two years. Three out of the four High Courts were functioning under Acting Chief Justices, and public confidence in the independence of the judiciary was deteriorating (Mian 2004, 176-177). The judgment was warmly welcomed across the board in Pakistani society, except in government circles (Waseem 2012, 24; Jen, and Abeyratne 2020). Hassan (2007) argued that the independence of the judiciary had been strengthened by the judgment. Though the judgment had positive effects on the independence of the judiciary by insulating judicial appointments from political intervention, there was also some valid criticism of it. Seervai (2013, 2964), a renowned expert on Indian Constitutional law, harshly criticised the judgment of the Indian Supreme Court and expressed the view that the judgment "bristle[d] with almost every fault which can be committed in a judgment". This criticism could be applied with the same force on the judgment of the Supreme Court of Pakistan, which was almost a reproduction of the Indian judgment in terms of matter and effect (Noorani 2012). Hamid Khan commented on this judgment that it had an inherent defect as the judges were personally interested in its outcome (Khan 2009, 599). In 2000, the Malaysian Court of Appeal adopted a different interpretation of the term "Consultation", and declared that "Consultation" is not equivalent to "Consent". There is a difference between the two terms; a Consultation means to refer a matter for opinion or advice (Dato' Seri Anwar Bin Ibrahim v Public Prosecutor 2000, 570).

Another flaw in the judgment was that it stayed silent on the issue of differences of opinion 
between the consultees. There have been some examples of such differences in the judicial history of Pakistan. Justice Cornelius, when he was the Chief Justice of Pakistan, did not agree often with the opinion of the Chief Justice of the West Pakistan High Court (Rizvi 2005, 1317). Moreover, another flaw in this judgment is related to the possible deceptive intent of the Chief Justice, Sajjad Ali Shah. The judgment declared the seniority principle binding for appointments of the Chief Justices of the High Courts but did not elaborate that this principle would also be applicable to the appointment of the Chief Justice of the Supreme Court (Mian 2004, 181). Sajjad Ali Shah had himself been appointed as Chief Justice of Pakistan by bypassing three senior judges in violation of the forty-year-old precedent that the most senior judge is appointed as the Chief Justice of Pakistan (Khan 2009, 595). However, just two years after the passing of this judgment, he fell prey to his own judgment. Following an episode of tension with his colleagues coupled with conflict with the government, Shah's fellow judges of the Supreme Court passed a judgment invalidating his appointment on the grounds of the principle of seniority set in the $A l$ Jehad Trust case (Asad Ali v Federation of Pakistan 1998, 161). The court declared that the principle of seniority set for the appointment of the Chief Justice of a High Court applies with more force in the appointment of the Chief Justice of the Supreme Court (Para c). In compliance with this judgment, the government withdrew the notification of his appointment as the Chief Justice of Pakistan (ICG 2004, 7).

The practical outcome of these judgments was that the Supreme Court arrogated the power of Appointments in the superior judiciary to itself (Lee 2010, 386). Justice (R) Fakhruddin G. Ibrahim (2010) argued that when an appointment was approved by the Chief Justice, it became binding on the executive to appoint that person except in exceptional cases, where the prime minister could record the reasons for his disagreement. In such cases the Chief Justice could review the appointment; however, primacy still rested with the Chief Justice. This judgment rendered the role of the executive in judicial appointments as ceremonial. Though the transformation of the system of judicial appointments in Pakistan from politicised towards judicialised was considered a positive step, this change had its own ramifications (Mullally 2009, 37). The system of consultation lacked transparency because of its secrecy, thereby resulting in mistrust towards the system and the rise of suspicions of corruption and nepotism within the legal community. The root cause of mistrust in this new format was the collegial control wielded by the Chief Justice. In theory, the Chief Justice was equal to his colleagues but in reality he was above all because of his administrative control over the judicial institutions (Khan and Shah $2003,21)$. The concentration of power in one person with regard to judicial appointments was a matter of concern as it could weaken judicial independence rather than strengthening it. The Chief Justice could become susceptible to immense political pressure for the sake of making favoured judicial appointments (Mullally 2009, 42). Lee $(2010,386)$ argued that "[t]he notion of judges appointing judges is however one that skews the separation of powers and also the doctrine of judicial accountability. It is a model which is not deployed in most countries". According to the Indian Judges case, the Chief Justice of the Supreme Court had to consider the views of two of the most senior judges of the Supreme Court though he was not bound to follow their advice (Supreme Court Advocates - on - Record Association v Union of India 1993, 702). Even the Indian Judges case was criticised as it again brought a lack of transparency because of collegial control (Lee 2010, 386). In the Pakistani Judges case the Chief Justice was not required to consider any advice, and was equipped with the unqualified power of judicial appointments. Hence, the same criticism applies with even more force in relation to the Pakistani Judges case.

Despite the transfer of power towards the Chief Justice there was a strong perception that there had been instances of political interference. Miss Bhutto strongly opposed the judgment and even ridiculed it, both in and outside Parliament (LaPorte 1997, 119). A few days after the pronouncement of the judgment, the government appointed a judge in the Supreme Court and a Chief Justice of the Sindh High Court without consulting the Chief Justice of Pakistan (Shah 
2009, 6). Similarly, Sharif in his second term was unhappy with the names of two out of the five candidates suggested by the Supreme Court. He tried to resist the recommendations of the Supreme Court by using different tactics, however due to the president's intervention he was compelled to notify the names recommended by the Supreme Court (Hussain and Khan 2012, 8889). Likewise, during Musharraf regime, the executive, while ignoring the seniority principle, bypassed Chief Justice Falak Sher of the Lahore High Court and elevated two junior Lahore High Court Judges to the Supreme Court. Mrs Justice Fakhar-un-Nisa Khokhar, who would have been the first female Chief Justice of the Lahore High Court, was also bypassed, and a junior judge, Iftikhar Hussain Chaudhary, a brother of the Governor of Punjab, was appointed as Chief Justice instead. The Chief Justice of the NWFP High Court, Shakirullah Jan, was elevated to the Supreme Court despite the fact that the Chief Justice of Pakistan had recommended Iftikhar Hussain Chaudhary for elevation (ICG 2004, 9).

Taken together, the various instances of elevation against recommendation show that at times the consultation process became meaningless in the face of the power of the executive or key players in the judiciary. The more powerful among the executive and judicial heads used their discretion in judicial appointments. During fragile democratic regimes, the Chief Justices used their sole discretion, and during military regimes, the military heads did the same. Even democratic governments made judicial appointments without consultation and claimed that consultation had taken place, whilst on the other hand the concerned Chief Justice denied that any consultation had actually taken place. The executive also showed reluctance to initiate the process of judicial appointments and kept key judicial appointments pending for longer periods in the hope of being able to choose their favoured candidates (Ibrahim 2010).

\section{Professionalised Model of Judicial Appointments in Pakistan}

The "professionalised model" is based on a system of independent judicial appointment commissions who make appointments from a pool of eligible candidates either directly or through competitive exams. In this model, although the final appointment is made by the executive, it possesses minimal or no discretion to deviate from the list finalised by the commission (Jowell 2010, 4-5). A judicial commission is, by tradition, a civil law institution; however, it has gradually gained popularity as a key element of reform in common law jurisdictions (UNODC 2006, 11). The composition of commissions varies across different jurisdictions. However, the most popular model seems to be a balance between members of the judiciary, political institutions and of the legal profession and civil society (Gee 2012, 132). The main focus remains that the political branches should not dominate in the composition of judicial commissions (Hlmann and Kunz 2011, 323). The logic behind the formation of judicial commissions is that because of the high value of judicial appointments in maintaining judicial independence, the process cannot be left exclusively in the hands of the executive or the parliament (Bell 2003). This fact was acknowledged by Article 4 of the Judges' Charter in Europe, which declared that judicial appointments should be made exclusively subject to "objective criteria designed to ensure professional competence" (EAJ 1997). According to the Charter, judges should be selected by an autonomous body substantially represented by judges. There should be no external and, especially, political influence in the process of judicial appointments.

However, Gee $(2012,132)$ disagrees with the above point of view and suggests that judicial selection cannot be protected from politicisation because the courts have authority of accountability over the political institutions. Hence, the transfer of the power of making judicial appointments from political institutions to judges does not provide immunity for the process from political considerations. He warns that the de-politicisation should not go to such extremes that the system lacks democratic legitimacy. Gee's perspective would have some substance if the 
judicial commission was comprised only of judges, because this type of commission would transfer the monopoly on judicial appointments from the executive to the judiciary. Jackson $(2012,72)$ goes one step further and argues that placing the power of judicial appointments in the hands of the head of the executive alone may bring more transparency and accountability into the system of appointments compared to the selection of judges through commissions. He further argues that judicial appointments through commissions comprising members from different backgrounds may cause accountability to be diminished.

The criticism by Gee and Jackson seems to be slightly emotional rather than rational. The appointment of judges based on merit instead of political patronage is the central feature of a reliable judicial appointments procedure. The averment that this target can be achieved while appointments are under the exclusive control of the executive is becoming hard to sustain (Malleson 2004, 104). The model of a judicial appointments commission does not absolutely rule out the involvement of the political branches in the selection process. This model involves all the important players in a constitutional system, and an example of it is the Judicial Appointments Commission in England. All three state organs including civil society and the legal fraternity have the chance to share in the process of judicial appointments and contribute their specific knowledge and expertise. The most prominent advantage of this model is that no individual or single organ of state can dominate and manipulate the judicial appointments process. Therefore, the model contains political and judicial legitimacy in a more transparent and comprehensive way. This type of model can therefore be declared the best model to follow for judicial appointments.

Even after the implementation of a judicialised model for judicial appointments in Pakistan, the lack of transparency and the ongoing tussle between the executive and the judiciary over judicial appointments continued. This resulted in deliberations regarding possible further refinements to the current system (Cotran and Lau 2005, 34-35). There was almost a unanimous demand for the establishment of a judicial appointments commission to make appointments in the superior courts (IBA 2008, 18; Hassan 2010). For instance, Lee (2010) suggested that "[t]o bolster trust and public confidence in the judicial institution, the most appropriate step which would ensure an appropriate role for the executive and the judiciary is the establishment of a judicial appointments commission". The International Bar Association Human Rights Institute (2007) in its report on Pakistan suggested that to ensure transparency there should be a judicial appointments commission with representation from all the provincial and federal stake holders to avoid the hegemony of any single branch.

In 2010, a new Article, 175A, was added in the Constitution the $18^{\text {th }}$ Constitutional Amendment. This amendment abolished the direct role of the prime minister and the president in judicial appointments and the appointment process was channelled through a Judicial Commission and a Parliamentary Committee. For appointments in the Supreme Court the commission was to be comprised of the Chief Justice of Pakistan as Chairman, two of the most senior Supreme Court Judges, a former Chief Justice or a former Supreme Court Judge to be nominated by the Chief Justice of Pakistan after consultation with two member judges, for a period of two years, the Federal Law and Justice Minister, the Attorney General and a senior Supreme Court advocate to be nominated by the Pakistan Bar Council for two years. The total number of the members was therefore seven, out of whom three were serving Supreme Court Judges, one retired Supreme Court Judge, one politician, one advocate and one Attorney General. For appointments in the High Courts, four more members were added to the Commission. These members would be the Chief Justice and another senior judge of the concerned High Court, the Provincial Law Minister and a senior advocate to be nominated by the concerned provincial Bar Council for a period of two years. For the appointment of a Chief Justice of the High Court, the most senior judge would be replaced by a former judge to be nominated by the Chief Justice of Pakistan after consultation 
with the two member judges from the Supreme Court. For the appointment of Federal Shariat Court Judges, its Chief Justice and the most senior judge would be included in the Commission. If the appointment being made was for a new Chief Justice then the senior judge would be replaced in the manner similar to that of the High Court. The Commission would by its simple majority recommend to the Parliamentary Committee one candidate against each vacancy. The Parliamentary Committee would be comprised of eight members in total: four members from opposition benches (two from the Senate and two from the National Assembly), and similarly, two members from each house from the treasury benches. Within fourteen days, the Committee would accept a recommendation with a simple majority or reject it with a two-thirds majority and in the case of its failure to do so, the recommendation would automatically be accepted. In the case of rejection by the Committee, the Commission would send another recommendation, and finally, the Committee would forward the recommendation to the president for appointment. Another important and notable change brought about by the $18^{\text {th }}$ Amendment was the appointment of the judges of the Federal Shariat Court through the same process.

These changes caused fresh controversy, as there were divergent responses from the intelligentsia of Pakistani society (Hussain and Kokab 2011, 88). Some believed it was a positive move because it replaced individuals with institutions (Waseem 2012, 25-26). The previous role of the president was substituted with the Parliamentary Committee and the role of the Chief Justice was substituted with the Judicial Commission (Habib and Zahraa 2012). The inclusion of representatives of the legal fraternity in the Judicial Appointments Commission was also welcomed because the positive input of the Bar was also desirable (Khan and Shah 2003, 25). According to Hasan Askari (2010), the self-acquired power of the Chief Justice with regard to binding consultations was neutralised with the establishment of a judicial commission.

There was also some strong criticism of these changes from the legal and political community (Hashmi 2018, 10). Ijazul Haq (2010), a former federal minister, declared the amendment "an insinuation and disguised move". He believed that the changes were dangerous, with the potential to politicise highly important national institutions. Hamid Khan believed that the ways in which the procedure of judicial appointments had been changed would result in huge meddling in judicial appointments by the executive and Parliament (Khan n.d). Though the legal community had reached an agreement that a system, like that introduced by the $18^{\text {th }}$ Amendment, should be adopted, they had reservations about the limited representation of the legal fraternity in the selection process. They expressed the view that the inclusion of political institutions in the selection process on a larger scale could be construed as an attack on judicial independence (ICJ 2011, 8-9; Cheema 2016, 458; Ahmed 2017, 497). Mahboob and Rizwan believed that the new process would politicise judicial appointments at both stages. A judge would have to win the confidence of the judicial commission and then he would have to gain the favour of the majority of the Committee. They expected that at both of these stages the votes would be cast on a political basis and that it would also become public. The public would perceive these appointments as politically motivated. They also criticised the condition of the most senior judge being appointed as a Chief Justice, arguing that this meant that the only criteria for this most senior appointment would be length of service instead of arguably more relevant criteria such as competency and performance (Hussain and Kokab 2011, 88). The Parliamentary Committee was armed with the power of veto against the recommendation of the Commission (Lunn and Thompson 2012, 19). However, despite the fact that the possibility of executive capture could not be ruled out and the courts were likely to strongly resist these changes, the changes would bring "transparency and meritocracy" to the system of judicial appointments, a prerequisite for an independent and respected judiciary.

Segments of society unhappy with these changes in the appointment process, including the Supreme Court Bar Association, challenged these changes in the Supreme Court of Pakistan in 
the Nadeem Ahmad v Federation of Pakistan case (2010). The petitioners asserted that these changes in the appointment procedure were against the principle of judicial independence, and against the "basic model" and salient features of the Constitution. The petitioners raised serious concerns over the formation and symmetry of the Commission and the veto power given to the Parliamentary Committee. The court agreed with the reservations of the petitioners and recommended that the number of the most senior Supreme Court Judges should be increased from two to four; that the Committee should give sound reasons for the rejection of any nomination; and that in such cases, nominations would be sent back to the Commission for reconsideration. If the Commission after reconsideration reiterated the same verdict, then it should become final and the president should implement it accordingly. The court further recommended that the in camera proceedings of the Committee should be recorded in detail. The court was also aware that it could be blamed for breaching the sovereignty of Parliament; hence it tried to clarify its position by stating:

"By making this unanimous reference to the Parliament for re-consideration, we did not consider the sovereignty of the Parliament and judicial independence as competing values. Both the institutions are vital and indispensable for all of us and they do not vie but rather complement each other so that the people could live in peace and prosper in a society which is just and wherein the rule of law reigns supreme... We had two options; either to decide all these petitions forthwith or to solicit, in the first instance, the collective wisdom of the chosen representatives of the people by referring the matter for reconsideration. In adopting the latter course, we are persuaded primarily by the fact that institutions may have different roles to play, but they have common goals to pursue in accord with their constitutional mandate." (Para 14)

The court, while admitting the good faith of Parliament behind the incorporation of these amendments, did not give its final verdict and chose instead to pass an interim order to demonstrate that it respected the legislative authority of the Parliament (Para 13). Many commended this judgment as the court showed judicial restraint and did not challenge the parliamentary authority by fully embracing the basic model and declaring the amendment null and void (Iqbal 2010; Kalhan 2013, 80, Dhawan 2020, 194). After making these recommendations, the court referred the matter back to Parliament to make further amendments in the appointment procedure keeping in view the recommendations of the Supreme Court (Nadeem Ahmad v Federation of Pakistan case 2010, Para 13).

This series of events was unique in the judicial and constitutional history of Pakistan in that a constitutional amendment was challenged in the Supreme Court by different segments of society and the court accepted these petitions for adjudication (Khan n.d; Jon and Thompson 2012, 9). The adjudication over the merit of a constitutional amendment was not per se an extraordinary issue. For instance, it is not unusual that the courts may test a constitutional provision to verify whether or not it violates human rights law or the obligations of a state under international law. However, in this case the Supreme Court expressed its desire that its views should be given priority over the decisions of Parliament, a stance which can become objectionable under the principle of "nullus iudex in causa sua" (Jon and Thompson 2012, 9). The Pakistani Parliament possessed all the necessary powers to pass any constitutional provision with only one condition: that it should not violate the limits prescribed by Allah. However, the judges were inclined to challenge the legislative authority of the Parliament by connecting the notion of judicial independence to the basic model of the Constitution. Following the judgment, the Pakistani Parliament agreed to accept most of those recommendations before it passed the $19^{\text {th }}$ Constitutional Amendment. However, the recommendation of the Supreme Court specifying that if the Judicial Commission reiterates the recommendation rejected by the Parliamentary Committee it shall become final, was not accepted by the Parliament. The rejection of this 
recommendation did not impair judicial independence; rather, if it had been accepted, it would have disturbed the balance of power set in place by the creation of the Judicial Appointments Commission and Parliamentary Committee, and resulted in a judicial supremacy over the country's elected institutions.

Although the demand of the Supreme Court to have the final say in the process of judicial appointments was rejected by Parliament, the Supreme Court did not give up its attempt to gain control of judicial appointments. Soon after the $19^{\text {th }}$ Amendment, the Parliamentary Committee rejected nominations for four Lahore High Court and two Sind High Court Judge appointments. These rejections were challenged in the Supreme Court of Pakistan in the Munir Hussain Bhativ Federation of Pakistan case (2011). The court declared that the rejection of the nominations by the Committee was justiciable and could be subjected to judicial review. The court declared that the Committee did not have sufficient institutional expertise to object to the findings of the Commission about the professional competence, legal insight, judicial expertise, worth and antecedents of the proposed candidates. Justice Jawwad S. Khawaja in his concurring judgment preferred judicial supremacy over judicial appointments. For justification of his view he relied upon the previous two judge's cases and the theory of judicial independence as the touchstone of the Constitution. Thus, the court repelled the grounds of rejection, set aside the order of the Committee and ordered the government to implement the recommendations of the Judicial Commission. Apparently, the effect of the judgment was to give supremacy to the Commission; however, in practical terms the Supreme Court regained its commanding authority over judicial appointments which it had possessed prior to the $18^{\text {th }}$ Amendment. The Court virtually annulled the effects of the $18^{\text {th }}$ and $19^{\text {th }}$ amendments through this judgment, because the role of the Parliamentary Committee in judicial appointments process became meaningless and purposeless (Ali and Jan 2018, 58). Like its Indian counterpart, the court construed that the judicial independence is based in gaining control of judicial appointments and ignoring the need for the existence of checks and balances in the appointment process (Nelson 2018, 334). Cyril Almeida (2010) pointed out after the Court's judgment on the $18^{\text {th }}$ Amendment that it meant that there had been practically no change to the previous appointment procedure. The Chief Justice of Pakistan would retain his key position in the appointment process and if Parliament rejected any nomination made by the Commission, the grounds for their rejection would be justiciable by the Supreme Court. Thus the move of the Supreme Court was widely criticised by informed circles of Pakistani society (Naqvi 2011; Jahangir 2011; Siddique 2011, 26-27; Cheema 2015, 197). This attempt of the judiciary to gain hegemony over judicial appointments and the harsh criticism of the situation suggests that the judicial appointment system is still not working satisfactorily. This fact became more visible when a member of the Parliamentary Committee criticised the ineffectiveness of the Committee and the Judicial Appointments Commission, by claiming that 126 judicial appointments had been made by Chief Justice Ch. Iftikhar on the basis of nepotism (Malik 2013). The role of the parliamentary committee as prescribed by the $18^{\text {th }}$ and $19^{\text {th }}$ Constitutional Amendments could have played a check and balance role in case the Judicial Commission selected some candidate based on grounds other than merit criteria. As discussed above, the potential benefits of a check and balance role of the Parliamentary Committee were rendered meaningless by the transfer of judicial appointments powers absolutely back in the hands of the Supreme Court. This dilemma can be resolved by introducing a new constitutional amendment to restore the check and balance role of the Parliamentary Committee according to the spirit of the 18 and $19^{\text {th }}$ Constitutional Amendments.

\section{Conclusion}

Pakistan has experienced politicised, judicialised and professionalised models of judicial appointments. Irrespective of the type of model implemented, the executive has generally been keen to appoint politically affiliated and subservient judges, and those judges were keen to 
appoint their own relatives and allies. The politicised model failed due to the lust of the executive to fill judiciary with its likeminded judges. Similarly, the judicialised model generated rift between the judiciary and the executive. The lack of transparency and the collegial control of the chief justice created mistrust on the judicial appointments through this system. The newlyadopted professionalised model was considered a good step towards the restoration of public confidence in the process of judicial appointments. However, the Supreme Court has reversed this model back into one more resembling a judicialised model through its judgment. The institutionalised model can provide better and trustworthy judicial appointments, however to achieve this target the hegemony of the Chief Justice over judicial appointments should be removed by making the role of the Parliamentary Committee meaningful and purposeful, as was intended in the $18^{\text {th }}$ Constitutional Amendment.

\section{References}

"Supreme Court Decision Undermines Legislature" (The Express Tribune, March 5, 2011).

Ahmed, Imran. 2017. "Strategic Constitutions': Constitutional Change and Politics in Pakistan." South Asia: Journal of South Asian Studies 40 (3): 481-499.

Ali, Rafia Naz, and Mohammad Jan. 2018. "Critical Analysis of the Role of Democratic Institutions in the Appointment of Judges of Superior Courts in Pakistan." Journal of Law \& Socie'y 49 (73): 51-62.

Al-Jehad Trust $v$ Federation of Pakistan, PLD 1996 SC 324.

Al-Jehad Trust $v$ Federation of Pakistan, PLD 1997 SC 84.

Almeida, Cyril. 2010. "Breathing room" Dawn, October 22.

Asad Ali v Federation of Pakistan, PLD 1998 SC 161.

Bell, J. 2003. "Judicial Appointments: some European experiences."Conference on" Judicial Reform: Function, Appointment and Model.

Blue, Richard, Richard Hoffman and Louis-Alexandre Berg. 2008. Pakistan Rule of Law Assessment - Final Report. USAID. <http://pdf.usaid.gov/pdf_docs/PNADO130.pdf>.

Bray, John. 1997. "Pakistan at 50: a state in decline?." International Affairs 73 (2): 315-331.

Bühlmann, Marc, and Ruth Kunz. 2011. "Confidence in the judiciary: Comparing the independence and legitimacy of judicial systems." West European Politics 34 (2): 317345.

Cameron, Edwin. 1990. "Judicial accountability in South Africa." South African Journal on Human Rights 6 (2): 251-265.

Cheema, Moeen H. 2015. "The Chaudhry Court: Rule of Law or Judicialization of Politics." in The Politics and Jurisprudence of the Chaudhry Court 2005-20013, edited by Moeen Cheema and Ijaz Gilani, 197. Karachi: Oxford University Press.

Cheema, Moeen H. 2016. "The" Chaudhry Court": Deconstructing the" Judicialization of Politics" in Pakistan." Washington International Law Journal 25 (3): 447-487.

Cheema, Moeen H. 2018. "Two steps forward one step back: The non-linear expansion of judicial power in Pakistan." International Journal of Constitutional Law 16 (2): 503-526.

Clarke, Anthony Peter. 2009. Selecting Judges: Merit, Moral Courage, Judgment and Diversity." High Court Quarterly Review 5 (2): 49.

Constitution (Eighteenth Amendment) Act, 2010.

Constitution (Nineteenth Amendment) Act, 2010.

Constitution of Malaysia.

Constitution of Pakistan 1956.

Constitution of Pakistan 1962.

Constitution of Pakistan 1973.

Cotran, Eugene, and Martin Lau. 2008. Yearbook of Islamic and Middle Eastern Law. Eds. Victor Kattan, and Chibli Mallat: Brill Academic Publishers.

DCA (Department for Constitutional Affairs) 2003. Constitutional Reform: A New Way of Appointing Judges

(Consultation

Paper,

CP10/03,) 
<http://webarchive.nationalarchives.gov.uk/20100512160448/dca.gov.uk/consult/jacomm ission/judges.pdf $>$.

Dhawan, Prannv. 2020. "'Reform That You May Preserve': Rethinking the Judicial Appointments Conundrum." Indian Journal of Constitutional Law 9: 186-196.

EAJ (European Association of Judges) 1997. Judges' Charter in Europe.

Evans, Simon, and John Williams. 2008. "Appointing Australian judges: A new model." Sydney Law Review 30: 295.

Garoupa, Nuno, and Tom Ginsburg. 2009. "Guarding the guardians: Judicial councils and judicial independence." The American Journal of Comparative Law 57 (1): 103-134.

Gee, Graham. 2012. "The Persistent Politics of Judicial Selection: A Comparative Analysis." Judicial Independence in Transition: 121-145.

Gee, Graham. 2017. "Judging the JAC: How Much Judicial Influence Over Judicial Appointments Is Too Much?." In Debating Judicial Appointments in an Age of Diversity, edited by Graham Gee and Erica Rackley, 152-182. Routledge.

Gibbs, Sir Harry. 1987. "The Appointment and Removal of Judges." Federal Law Review 17 (3): 141-150.

Gill, Rebecca D. 2012. "A Framework for Comparative Judicial Selection Research With an Application to Gender Diversity on High Courts." Available at SSRN 1982705.

Goldschmidt, Jona, David Olson, and Margaret Ekman. 2008. "Relationship between Method of Judicial Selection and Judicial Misconduct." Widener Law Journal 18: 455.

Government of India Act 1935

Habib, Rao Imran and Mahdi Zahraa. 2012. "Judicial Independence in Pakistan: A Brief Historical Account" Harvard Asia Quarterly 14(3): 25-31.

Haq, Ijaz Ul. 2010. "Who is Supreme?" The News International, May 19.

Haq, Noor Ul. 2011. Eighteenth Amendment to the 1973 Constitution, IPRI Publications <http://ipripak.org/factfiles/ff134.pdf>.

Hashmi, Zeeshaan Zafar. 2018. "Unconstitutional Constitutional Amendments or Amending the Unamendable: A Critique of District Bar Association Rawalpindi v. Federation of Pakistan." Pakistan Law Review 9: 1-49.

Hassan, Ahamd. "Parties strike accord on 18th Amendment" (Dawn, April 01, 2010). <http://www.dawn.com/news/528244/parties-strike-accord-on-18th-amendment $>$.

Hassan, Parvez. 2007. "Environmental Protection, Rule of Law and the Judicial Crisis in Pakistan." Asia Pacific Journal of. Environmental Law 10 (3\&4): 167.

Hayo, Bernd, and Stefan Voigt. 2014. "Mapping constitutionally safeguarded judicial independence-A global survey." Journal of Empirical Legal Studies 11 (1): 159-195.

Hussain, F. 2011. The Judicial System of Pakistan (Supreme Court of Pakistan) <http://www.supremecourt.gov.pk/web/user_files/File/thejudicialsystemofPakistan.pdf $>$.

Hussain, Fayyaz Ahmad, and Abdul Basit Khan. 2012. "Role of the Supreme Court in the Constitutional and Political Development of Pakistan: History and Prospects." Journal of Politics and Law 5 (2): 82.

Hussain, Mahboob, and Rizwan Ullah Kokab. 2012. "Eighteenth Amendment in the Constitution of Pakistan: Success and Controversies." Asian Social Science 8 (1): 81.

IBA (International Bar Association). 2008. The Rule of Law and Human Rights in the Legal System of Pakistan. Report. <https://www.ibanet.org/Document/Default.aspx?DocumentUid=cccdd2a5-4943-45199c09-a131596bdd3c >.

Ibrahim, Fakhruddin G. 2010. 'Pakistan: Again a Judicial Crisis - Not a Bonafide Crisis but a Crisis Created for Ulterior Reasons'. Asian Human Rights Commission http://www.humanrights.asia/document-type/forwarded-article/page/19/ .

ICG (International Crisis Group). 2004. Building Judicial Independence in Pakistan. Asia Report No 
< $\underline{\text { https://www.files.ethz.ch/isn/28401/086_building_judicial_independence_in_pakistan.p }}$ df $>$.

Independence Act 1947.

Iqbal, Anees. 2012. "The Process of Judicial Appointments in Pakistan under the 1973 Constitution." The Journal of Humanities and Social Sciences 20 (1): 15-28.

Iqbal, Nasir. 2010. "Parliament doesn`t have unfettered powers: CJ." Dawn, August 17.

Iqbal, Nasir. 2010. "Parliament not under trial, says CJ." Dawn, July 28.

Jackson, Vicki C. 2012. "Judicial Independence: Model, Context, Attitude" in Judicial Independence in Transition, edited by Anja Seibert-Fohr, 19-86. Berlin, Heidelberg: Springer.

Jowell, Jeffrey. 2010. "The Growing International Consensus in Favour of Independent Judicial Appointment Commissions." Judicial Appointments: Balancing Independence, Accountability and Legitimacy.

<http://www.keithetherington.co.uk/downloads/files/JA_web.pdf $>$.

Kalhan, Anil. 2013. "“Gray Zone” Constitutionalism and the Dilemma of Judicial Independence in Pakistan" Vanderbilt Journal of Transnational Law 46 (1): 1- 96.

Khan, Hamid. 1997. "Judicial appointments in the perspective of Independence of Judiciary" Pakistan Law Journal: 177.

Khan, Hamid. 1999. The Judicial Organ. Lahore: Freedom Forum for Human Rights and Development.

Khan, Hamid. 2009. Constitutional and Political History of Pakistan. $2^{\text {nd }}$ ed. USA: Oxford University Press.

Khan, Hamid. "Role of Independent Judiciary in Countries of South Asia, Particularly Pakistan" $<$ http://www.supremecourt.gov.pk/ijc/Articles/2/3.pdf $>$.

Khan, Hamid. "Struggle of the Constitutional Court in Pakistan for judicial independence". <http://ebookbrowse.com/struggle-of-the-constitutional-court-in-pakistan-for-judicialindependence-hamid-khan-pdf-d180137522>.

Khan, Masood and Niaz A. Shah. 2003. 'Judicial Appointments in Pakistan' Institute of Governance Public Policy and Social Research Queen's University Belfast, Working Paper QU/GOV/5/2003.

LaPorte Jr, Robert. 1997. "Pakistan in 1996: starting over again." Asian Survey 37 (2): 118-125.

Lee, Hoong Phun. 2010. "Judiciaries in Crisis-Some Comparative Perspectives." Federal Law Review 38 (3): 371-389.

Legg, Thomas. 2001. "Judges for the new century." Public law 1: 62-76.

Legg, Thomas. 2004. "Brave New World-The New Supreme Court and Judicial Appointments." Legal Studies 24 (1- 2): 45-54.

Lunn, Jon and Gavin Thompson. 2012. Pakistan in 2013. Research Paper 12/76, House of Commons Library. <www.parliament.uk/briefing-papers/RP12-76.pdf>.

Madison, James. The Federalist <https://www.csus.edu/indiv/f/friedman/fa2019/govt1/schedule/B/FED\%2051.pdf >.

Malik, Hasnaat. 2013. "'Ineffective' Role in Appointment of Judges to Superior Courts: Parliamentary Committee Invites Lawyers for Consultations." Daily Times, December 23.

Malleson, Kate. 2004. "Creating a judicial appointments commission: which model works best?." Public Law 1: 102-121.

Mehmood, Sultan. 2020. "Judicial Independence and Development: Evidence from Pakistan." halshs-03054106. <https://halshs.archives-ouvertes.fr/halshs-03054106>.

Mehsood, Mobina, Fawad Khan, and Raza Ullah Shah. 2017. "Analysis of the Independence of Superior Judiciary Under Civilian Governments in Pakistan: From 1947 till 2009." Global Educations Studies Review 2 (1): 25-31.

Mian, Ajmal. 2004. A Judge Speaks Out. New York: Oxford University Press.

Mullally, Siobhan. 2009. "A Long March to Justice: A Report on Judicial Independence and Integrity in Pakistan." International Bar Association, Human Rights Institute. 
Nadeem Ahmad v Federation of Pakistan, PLD 2010 SC 1165.

Naqvi, Faisal H. 2011. "Protecting the Independence of the Judiciary-I" The Express Tribune, March 13.

Nelson, Matthew J. 2018. "Indian Basic Model Jurisprudence in the Islamic Republic of Pakistan: Reconfiguring the Constitutional Politics of Religion." Asian Journal of Comparative Law 13 (2): 333-357.

Noorani, A. G. 2012. "Judicial Appointment or Judicial Incest?" Criterion Quarterly 6(2). <http://www.criterion-quarterly.com/judicial-appointment-or-judicial-incest/>.

Office of the High Commissioner for Human Rights in Cooperation with the International Bar Association. 2003. Human Rights in the Administration of Justice: A Manual on Human Rights for Judges, Prosecutors and Lawyers, United Nations, Professional Training Series No 9 <http://www.ohchr.org/Documents/Publications/training9Titleen.pdf > .

Oral application by appellant in Dato' Seri Anwar Bin Ibrahim v Public Prosecutor [2000] CLJ 570.

Peri, Antonina. 2012. "Judicial independence vs. judicial accountability. Judicial selection models for Constitutional Courts. A comparative analysis" Comparative Law Review 3(1): 1-30.

Phillips, Lord. 2011. "Judicial independence and accountability: a view from the Supreme Court." Lecture delivered at the UCL Constitution Unit, launch of Research Project on The Politics of Judicial Independence 8.

Report on the ICJ Mission to Pakistan. Autumn 2011. < content/uploads/2012/06/Pakistan-ICJ-mission-fact-finding-mission-report-2012.pdf $>$.

Rizvi, Hassan Askari. 2010. "Analysis: Amending the constitution" Daily Times, April 11.

Rizvi, Syed Shabbar Raza. 2005. Constitutional Law of Pakistan: Text, Case Law and Analytical Commentary. $2^{\text {nd }}$ ed. Lahore: Vanguard.

Roth, Lenny. 2012. Judicial Appointments. NSW Parliamentary Library Research Service, Briefing Paper No 3/2012.

Sackvill, R. 2008. "Three issues facing the Australian judiciary" Judicial Officer's Bulletin 20(3): 17.

Seervai, H. M. 2015. Constitutional Law of India. $4^{\text {th }}$ ed. Gurgaon. University Law Publishing.

Shah, Amanullah and Bahadar Shah. 2008. "STUDY OF THE JUDICIAL APPOINTMENT IN PAKISTAN." Gomal University Journal of Research 24 (1): 181-188.

Shah, Amanullah. 2009. "STUDY OF THE CONSTITUTIONAL INDEPENDENCE OF THE SUPERIOR JUDICIARY IN PAKISTAN." Gomal University Journal of Research 25 (2): $1-10$.

Shetreet, Shimon. 1987. "Who will judge: Reflections on the Process and Standards of Judicial Selection." Australian Law Journal 61(12): 766- 778.

Siddique, Osama. 2011. Approaches to Legal and Judicial Reform in Pakistan: Post Colonial Inertia and the Paucity of Imagination in Times of Turmoil and Change, DPRC Working Paper $\quad 4 \quad<$ http://www.lprn.org.pk/wp-content/uploads/2015/07/DPRC-WP4Siddique.pdf $>$.

Stevens, Robert. 2004. "Reform in haste and repent at leisure: lolanthe, the Lord High Executioner and Brave New World." Legal Studies 24 (1- 2): 1-34.

Supreme Court Advocates - on - Record Association v Union of India, (1993) 4 SCC 441.

The 19th IBA Biennial Conference, New Delhi, 22 October 1982.

UNODC (United Nations Office on Drugs and Crime). 2006. Access to Justice: The Independence, Impartiality and Integrity of the Judiciary. Criminal Justice Assessment Toolkit. <http://polis.osce.org/library/f/2700/531/UN-AUS-RPT-2700-EN-531>.

Wallace, J. Clifford. 2001. "An essay on independence of the judiciary: Independence from what and why." NYU Annual Survey of American Law 58: 241.

Waseem, Mohammad. 2012. "Judging democracy in Pakistan: Conflict between the executive and judiciary." Contemporary South Asia 20 (1): 19-31. 
Williams, George, and Rachel Davis. 2003. "Reform of the judicial appointments process: gender and the bench of the High Court of Australia." Melbourne University Law Review 27 (3): 819.

Winterton, George. 1987. "Appointment of federal judges in Australia." Melbourne University Law Review 16: 185.

Yap, Po Jen, and Rehan Abeyratne. 2020. "Judicial Self-Dealing and Unconstitutional Constitutional Amendments in South Asia." International Journal of Constitutional Law July 27 (I-CON) (2021, Forthcoming), Available at SSRN. <https://ssrn.com/abstract=3661026>. 